\title{
The Baikal
}

\section{Rift System}

\author{
by Nikolai A. Logatchev
}

The Baikal rift of Siberia is a $1800 \mathrm{~km}$-long system of faults and rift valleys associated with a domal uplift. Its central segment is located at the junction between the Sayan-Baikal mobile belt and the Siberian craton in a "weakened" zone from which the rift propagated to the northeast and southwest. The Baikal system is characterized also by basaltic magmatism of a rather monotonous composition. Rifting in East Siberia was an independent phenomenon not connected with the collision between India and Eurasia, but rather the result of local heating and gravitational instability of the lithosphere caused by upwelling of the asthenosphere.

\section{Introduction}

The geology and geophysics of the Baikal rift zone were thoroughly studied during the Upper Mantle and the Geodynamics programs (Logatchev and Mohr, 1978). Since then, productive investigations. of deep-seated structure and seismicity have been conducted in the $800 \mathrm{~km}$-long zone extending from the northern end of Baikal eastward to the Olekma River. In addition, heat flow and seismo-acoustic measurements have been carried out recently in Lake Baikal. This lake (Fig.1) contains about $23000 \mathrm{~km}^{3}$ of fresh water and is the world's deepest $(1620 \mathrm{~m})$ intracontinental water reservoir; its bottom lies $1165 \mathrm{~m}$ below sea level. In 1977, the Canadian-made manned submersible carried out studies in southern Lake Baikal to a depth of $1410 \mathrm{~m}$ (Fig.2).

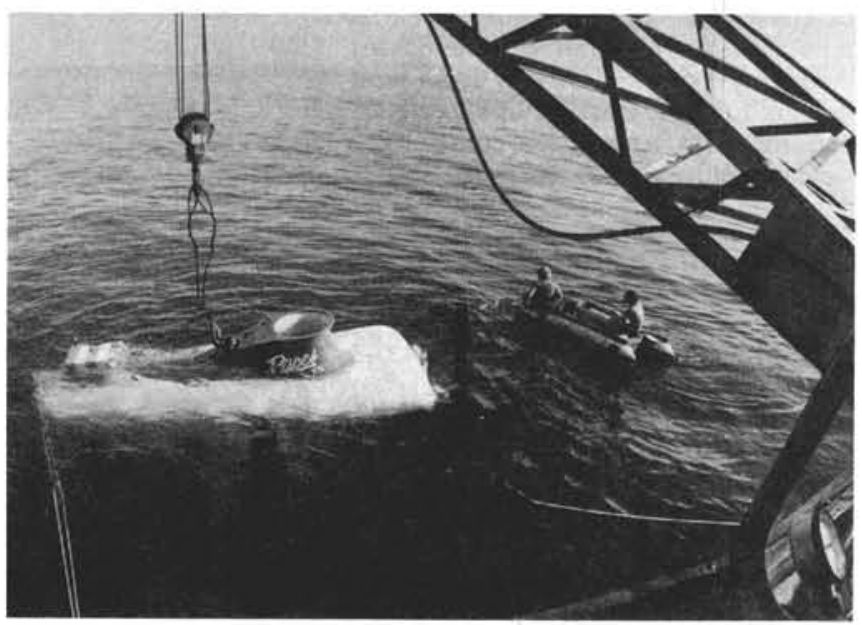

Figure 2: The Pisces manned submersible about to dive in southern Lake Baikal, August 1977.

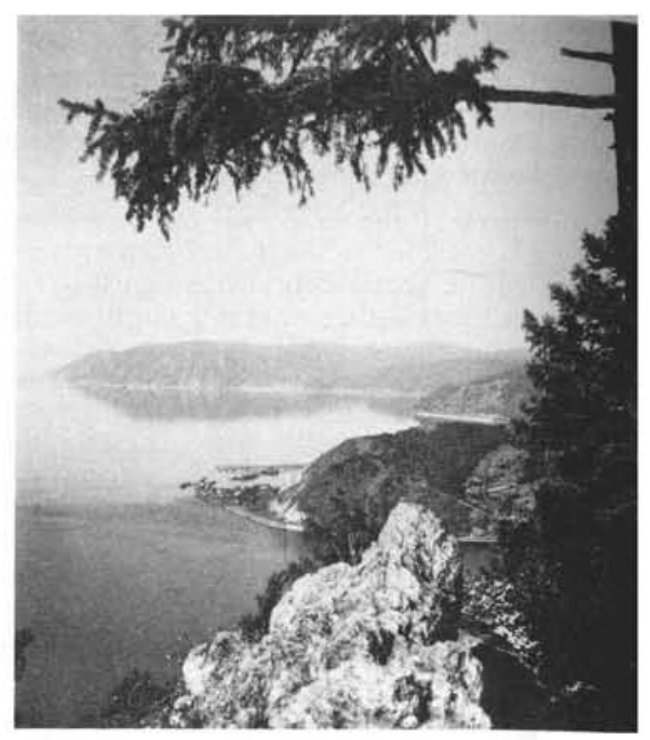

Figure 1: The southern flanks of Lake Baikal looking west ward across the inlet to the Angara River (foreground riaht) through which $63 \mathrm{~km}^{3}$ of water flow out annually.

\section{Morphology and Regional Structure}

The Baikal system of rift depressions and faults (Fig. 3) covers a lengthy belt of the southern uplands of East Siberia, extending from northern Mongolia to southern Yakutia. It is confined to the Sayan-Baikal domal uplift, which is the highest part of East Siberia, having been raised to 2500 $3000 \mathrm{~m}$ by Cenozoic movements (Fig.4). The $1500 \mathrm{~m}$ contour line of the Cretaceous-Palaeogene erosion surface in Figure 3 outlines the general shape of this uplift. It consists of two culminations separated in the South Baikal basin by a saddlelike depression to which the delta of the Selenga River, the main tributary of Lake Baikal, is conf ined.

There is a symmetry in the Baikal regional structure: in the saddle between the two uplift culminations, with their dispersed faults and rifts, the centre of the entire Baikal rift is marked by the South Baikal depression, at $6000 \mathrm{~m}$ the deepest in the whole system. The culminations differ in size, shape and in the arrangement of their faults and depressions. The northeastern culmination is more extensive than the southwestern, and it has a more or less constant orientation in the structural fabric of its Precambrian basement. In the southwestern culmination the strike of the faults and rift valleys changes sharply from latitudinal to meridional, and there is a marked contrast between rift forms and basement structures.

The Baikal rift zone runs close to the edge of the Precambrian Siberian platform. The central segment of the zone occupied by Lake Baikal stretches for about $500 \mathrm{~km}$ along the deep-seated marginal suture that separates the cratonic area from the Sayan-Baikal mobile belt, consisting of both Precambrian and Early Palaeozoic fold systems. At both terminations of the South Baikal depression, Cenozoic faults and grabens veer from the craton into the fold belt, indicating less dependence on the basement structural anisotropy.

In the northeast, the Baikal rift system penetrates into the Archean of the Aldan shield where it dies out due to the thickening of the lithosphere at the transition from the fold belt to the craton (Logatchev and Florensov, in Logatchev and Mohr, 1978). The Chara and Tokka depressions (Fig. 3) are the last segments of the rift zone located in the craton, and they cross its structural fabric at a right angle. This direction was apparently not suitable for rift propagation, though it coincides with the general strike of the whole zone. 
The direction around the Aldan shield along the Stanovik and Dzhugdzhur systems of deep-seated faults is evidently more favourable, for in the Olekma valley region there are small rift-like depressions, and several strong earthquakes (magnitude 6.5 to 7 ) have occurred there within the last thirty years. Their focal mechanisms are similar to those of rift earthquakes (Misharina, 1967), and the way is open to the east for propagation of the Baikal rift.

Another situation exists in the southwestern culmination of the rift zone. The nor th-south rift structures of North Mongolia are limited in the south by the east-west Balnai fault (Fig.3), which was rejuvenated as a sinistral strikeslip fault by the strong (magnitude 8.2) earthquake of 1905 . This shear zone of deep-seated origin separates two large lithospheric blocks and serves as a barrier preventing the Baikal rift from extending southward. The branching of the Baikal rift in the three depressions of Khubsugul, Darkhat and Busingol also indicates the dispersion of rifting energy throughout a larger volume of the lithosphere than underlying the single

Tunka graben. Moreover, at the western termination of the Baikal rift, subhorizontal north-south compression prevails at present, in contrast to the rest of the rift zone where extension across strike dominates (Misharina, 1967; Misharina et al., 1983; and see page 43 this issue of Episodes - Ed.).

\section{Rift Valleys and Faults}

The Baikal system consists of 13 large individual depressions arranged locally in parallel and separated from each other by transverse or diagonal "cross-pieces" (Fig. 3). The Lake Baikal basin (Figs. 5 and 6 ) is formed by the two en echelon depressions of South and North Baikal, which are separated by the diagonal uplift of Olkhon Island and the underwater Akademichesky Range. Each of the Lake Baikal depressions is $400 \mathrm{~km}$ long and up to $70-75 \mathrm{~km}$ wide, whereas other mature depressions in the rift system vary from a few tens to $200 \mathrm{~km}$ in length and from 35 to $40 \mathrm{~km}$ in width. Alongside the large depressions there are some narrow PleistoceneHolocene fault trenches ranging in length from a few $\mathrm{km}$ to several tens of $\mathrm{km}$.

The thickness of sediments in the basins usually varies from 1500 to $2500 \mathrm{~m}$, with the maximum (about $6000 \mathrm{~m}$ ) recorded in the South Lake Baikal depression. A borehole $3000 \mathrm{~m}$ deep in the Selenga delta region was stopped in Late Eocene to Early Oligocene sediments. The sedimentary infill of the basins is a mixture of fluvial, proluvial, lacustrine, palustrine, glacial, fluvioglacial and eolian deposits. Lacustrine and fluvial sediments prevail inside the basins, changing to subareal facies in the vicinity of the adjacent mountains.

The rift depressions are bounded on one or both sides by high fault scarps rising 1500 to $2000 \mathrm{~m}$ above the basin floors. The northern slopes of most depressions are higher and steeper than the southern flanks, and this results in a characteristic structural and morphological asymmetry. The crystalline basement of the depressions is locally cut by small faults, but in general the rifts follow the ductile structures in the basement.

Faults of different trends and ranging in age from Precambrian to Cenozoic play a dominant role in the structure of the rift system. Most of the large faults are normal or obliqueslip, with vertical displacements ranging locally to $3000-$ $4000 \mathrm{~m}$. The strike-slip faults can be seen on both flanks of the rift zone, and indirect evidence suggests horizontonal
RIT DEPRESSIONS (Numbered citcles)

$\begin{array}{ll}\text { 1. Busingol 10. Baunt } \\ \text { 2. Darkhat } & 11 . \text { Muya }\end{array}$

2. Oarkiat Muya

Thussugul 12 Chara

4. Tunka

5 South Bakal

6. North Baikal

7. Bargurin

8. Upper Angara

13. Tokka

Angara

$100^{\circ}$

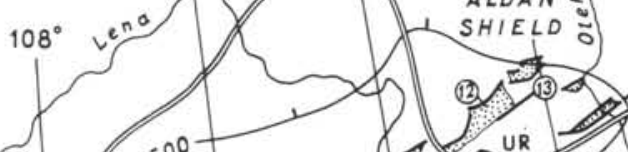
. )

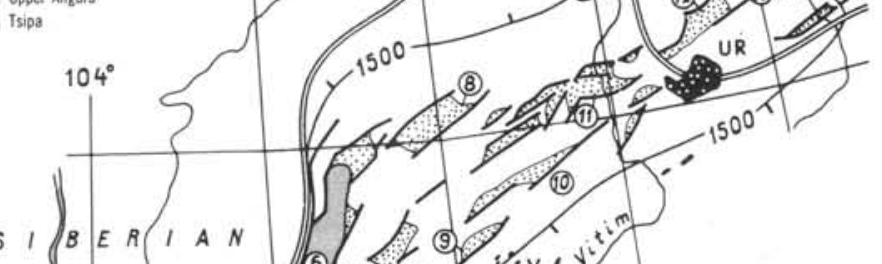
Baikal rift. V - Vitim plateau, UR - Udokan Range. Lake Baikal shaded.

displacements of a few $\mathrm{km}$. Focal mechanisms (Misharina et al, 1983) indicate that the central segment of the rift zone (Baikal depression proper) is being formed under the action of a tensional stress field, and the general extension of the crust, including plastic thinning, is estimated by Yu.A. Zorin at 15 to $25 \mathrm{~km}$. Along the rift zone flanks (especially the western ones) the crustal extension is combined with sinistral strike-slip.

The Baikal rift zone is a complex intraplate boundary resulting from the initial divergence of the lithosphere in East Siberia. Nevertheless, it is hard to predict whether the

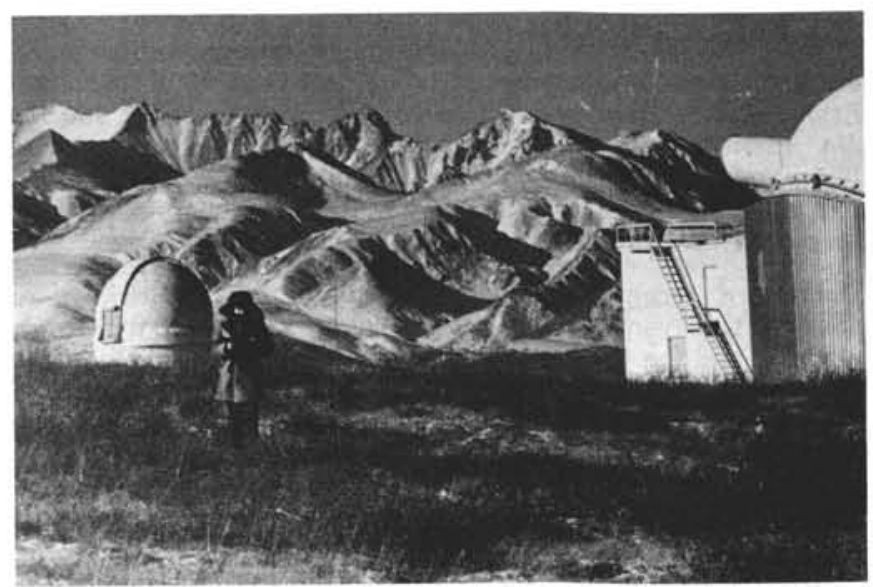

Figure 4: Mountains between the Tunka and Khubsugul depressions with the Munku-Sardyk massif, the highest peak of East Siberia (3491 $\mathrm{m}$ ) in the background ( $X$ marks location on Fig. 3). In the foreground a solar coronograph and a chromospheric telescope are located on an ancient erosion surface about $2000 \mathrm{~m}$ above sea level. 

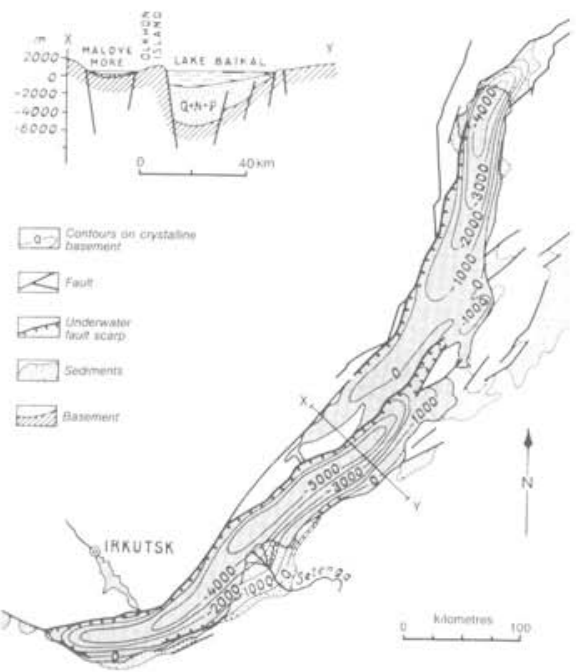

Figure 5: The structure of the Lake Baikal depression, showing a typical cross section. Q+N+P; Quaternary, Neogene and Palaeogene. Shading indicates the extent of the lake.

lithospheric extension will progress to complete crustal disintegration (as in the Red Sea rift), whether the continental lithosphere will be replaced by the oceanic lithosphere, or whether rifting will cease in this continental environment. The Baikal system of rejuvenated ancient faults and newly formed faults reflects elastic destruction of the upper lithosphere. Because of viscosity changes with depth, the lower crust and upper mantle are likely to deform plastically under the action of asthenospheric upwelling and lithospheric necking below the rift valleys.

\section{Volcanism}

Volcanism has played a subordinate role in the development of the Baikal rift though there are simple multilayered basalt plateaus and cinder cones. Whereas in the Kenyan and Ethiopian rifts the total volume of volcanics is about 500000 $\mathrm{km}^{3}$ (Baker et al., 1972 for a general comparison between the Baikal and Kenyan rifts see Logatchev, Zorin and Rogozhina, $1983 \mathrm{a}, 1983 \mathrm{~b}$ - Ed.), in the Baikal rift, which is similar in area, their volume does not exceed $6000 \mathrm{~km}^{3}$.

There are three main volcanic areas, from southwest to nor theast: Sayan-Kharnar-Daban-North Mongolia, the Vitim plateau, and the Udokan Range (Fig. 3). The first field is the most prominent, containing at least $50 \%$ of the entire volume of young volcanics. Lava sheets up to $500-600 \mathrm{~m}$ thick are widely distributed here, and small cinder cones and dikes are rarer. Stratovolcanoes are absent, indicating the prevalence of fissure eruptions. The lava sheets are usually not confined to rift depressions and bounding faults but are located on the uplifted shoulders of the rift valleys. The Tunka depression is, however, an exception, for basalts are regularly in tercalated with sediments and comprise $20 \%$ of its $2500 \mathrm{~m}$ thick infill (Fig. 7). In other depressions, including Lake Baikal, lava covers are absent.

An unexplained paradox is the absence of volcanics from the Lake Baikal depression. The lithosphere below the lake is

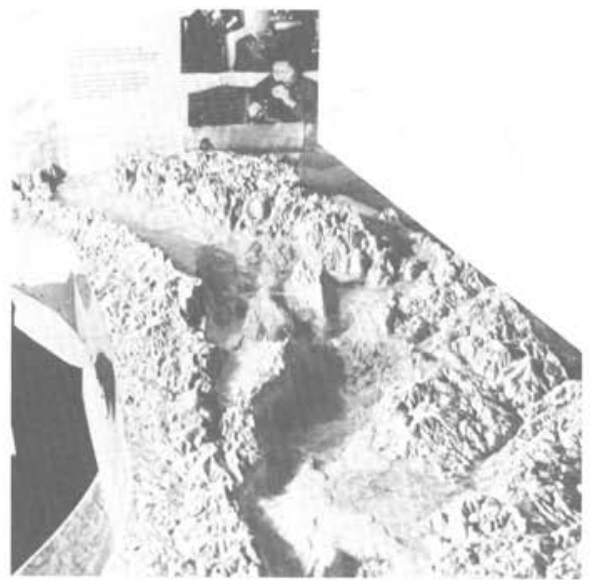

Figure 6: V.I. Galkins's relief model of the Baikal depression, looking to the NNE. Selenga River delta in right foreground. Vertical scale is 7 times the horizontal.

greatly thinned and extended as compared to other segments of the rift zone (Zorin, 1981). Rare Cenozoic basalt dikes occur in the slopes of the depression, and on the Ushkany Islands, which are a part of the underwater Akademichesky Range, small vents and dikes of biotite, augite and melilitebearing porphyrites with an age of 52 Ma have been found (Yeskin et al., 1978). These intrusive bodies formed during the initial rifting stage, and may have intruded into the crust prior to the subsidence of the depression. Such a situation is similar to that of the Upper Rhine graben where subvolcanic plugs and dikes ( 45 to $90 \mathrm{Ma}$ ) intruded into the crust long before graben formation in the Middle Eocene (Neugebauer and Temme, 1981).

Unlike the volcanic rocks of the rifts of East Africa and Central Europe, those in the Baikal rift have a rather monotonous composition, mainly alkaline olivine basalts. In rare cases there are continuous variations in chemical composition, from mildly alkaline basalts and trachybasalts to tholeites. The main reason for the insignificant degree of magmatic differentiation is the long-term existence of melting sources at the same depth within the upper mantle and the ease of melt transfer through fissures to the surface.

The volcanic rocks from the Udokan plateau are, however, markedly differentiated, ranging from mildly alkaline compositions (alkaline olivine basalt-trachyte) to more highly alkaline basanitoid and nepheline mugearite. The Udokan volcanics were evidently connnected with a possible deepening of the upper mantle melting source, due to changes in the tectono-thermal system at its transition from the lithosphere beneath the fold belt to the cooler and thicker lithosphere of the Aldan shield. Yet the Baikal rift volcanics on the whole are differentiated less than volcanics from other zones of Cenozoic continental rifting, such as East Africa, Central Europe, and Western U.S.A., including the Rio Grande rift. Acid differentiates and strongly alkaline rocks with carbonatite are unknown in the Baikal system, and intermediate rocks (trachyte, mugearite, benmoreite) are rare, being found only in the Udokan range. 
Basalts from the Baikal volcanic province contain therzolite and pyroxene nodules whose composition suggests that the uppermost mantle here consists of spinel lherzolite with pyroxenite lenses underlain by garnet lherzolite. The mineral and chemical compositions of the nodules, together with physical and chemical modelling, suggest that the parent melts could have formed through partial melting ( 5 to $10 \%$ ) of spinel therzolite enriched by alumina at a depth of no more than 80 to $100 \mathrm{~km}$. Melt fractionation in the mantle has resulted in formation of large cumulate inclusions of pyroxene, anorthoclase, kaersutite, titanophlogopite, garnet, spinel and titanomagnetite.

The distribution of volcanic rocks shows the independence of volcanicity from rift structure formation in the upper lithosphere. Structural development and magmatism are thus equivalent manifestations of the rifting process, a feature of Cenozoic rifting in East Siberia, which has not yet been properly explained.

\section{A Two-Stage Evolution}

The sedimentary infill of the Baikal rift depression can be subdivided into two parts, differing in composition and structure and corresponding to two evolutionary stages. In the lower part of the section are Eocene, Oligocene, Miocene and Lower Pliocene sediments composed of sandstone, siltstone, argillite and clay, with rare beds of brown coal, diatomite and marl mainly close to the periphery of the depression. These lacustrine, palustrine and fluvial sediments accumulated under subtropical (Eocene) to moderately warm (Oligocene, Miocene) climatic conditions, and they lack the coarsegrained marginal facies of a conglomerate or fanglomerate type.

From the Eocene to Miocene, the sedimentary basins were wider than in the Pliocene to Quaternary, because the topographic contrasts were less and the rates of tectonic movements lower than in the latter period. Plateau-like uplifts surrounding the depressions were cut by shallow river valleys. The relative variations in heights of the uplifts ranged from 400 to $500 \mathrm{~m}$ to judge from the morphology of the surface buried below Oligocene-Miocene basalts in the Khamar-Daban, East Sayan and Udokan ranges.

The upper strata (Middle Pliocene - Quaternary) differ from the lower ones, for they are coarse-grained sediments most clearly developed at the margins of sedimentary basins, where slightly fragmented sandy-gravel, pebble and boulder deposits prevail. At the margins of the depressions, the upper strata overlie the lower with unconformity and washout, indicating increased tectonic movements during the Middle Pliocene. At that time the boundaries of the depression reached their present position, and contrasts in elevations between neighbouring depressions and uplifts sharply increased. Crustal movements are still taking place at present, as can be seen by repeated levelling surveys and by the seismicity, which is the highest among all other continental rifts.

As to volcanism, the largest volume of basalt was extruded in the early evolutionary stage, and by Pliocene-Quaternary times the volcanic manifestations had decreased. The twostage rifting is typical not only of the Baikal rift zone, but is also well illustrated in the Upper Rhine graben (Illies, in Ramberg and Neumann, 1978). It is characteristic of rift zones with voluminous volcanicity (East Africa) and is common of Cenozoic rifting in continental environments (Logatchev in Ramberg and Neumann, 1978; Logatchev et al., 1983, 1983b-Ed.).

\section{Deep-Seated Structures and Mechanism of Formation}

The velocity of $\mathrm{P}$-waves at the Moho discontinuity is 7.7 $\mathrm{km} / \mathrm{sec}$ below the Baikal rift zone, as compared to 8.1-8.2 $\mathrm{km} / \mathrm{sec}$ below the Siberian platform and Transbaikalia (Krylov et al., 1981). Anomalously low velocities in the mantle beneath the rift zone are also indicated by P-wave delays
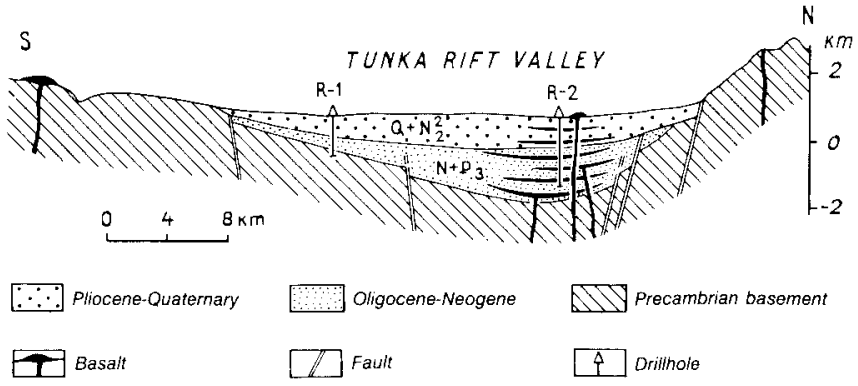

Figure 7: Cross section of the Tunka depression.

from distant earthquakes and explosions. At subvertical emergence of seismic rays, the delays are about one second (Rogozhina and Kozhevnikov, 1979), indicating that the thickness of the layer producing the delay is no less than 150 to $200 \mathrm{~km}$. In other words, there is an upwelling of the asthenosphere reaching the base of the crust here.

The width of the upper part of this upwelling corresponds roughly to that of the domal uplift $(200$ to $300 \mathrm{~km})$ and exceeds by many times the crustal extension necessary for the formation of the rift depression $(15$ to $25 \mathrm{~km})$. A straightforward mechanical extension of the lithosphere would not provide the necessary room for such a wide as thenospheric upwelling. Numerical modelling (Zorin, 1981) has indicated the possibility of asthenospheric uprise as a result of separation of lithospheric blocks sinking in and possibly being assimilated by the asthenosphere. The ductile extension of the lithosphere was not important in permitting asthenospheric upwelling, but it was prominent for the formation of the rift depressions.

When the asthenospheric material reached the Moho, its upward movement ceased because its density exceeded that of the crust. Since then ( 3 to $5 \mathrm{Ma}$ ago), there have been lateral movements in the asthenospheric upwelling, resulting in intense crustal extension, considerable vertical movements along faults and deepening of the rift depressions. Because of the existence of a thick, cold lithosphere to the nor th and northwest of the rift, a southeastward migration of the as thenospheric material appears to have been most likely (Fig. 8). This situation resulted in an asymmetry in the rift depressions and the distribution of volcanic fields along the southeastern margin of the domal uplift.

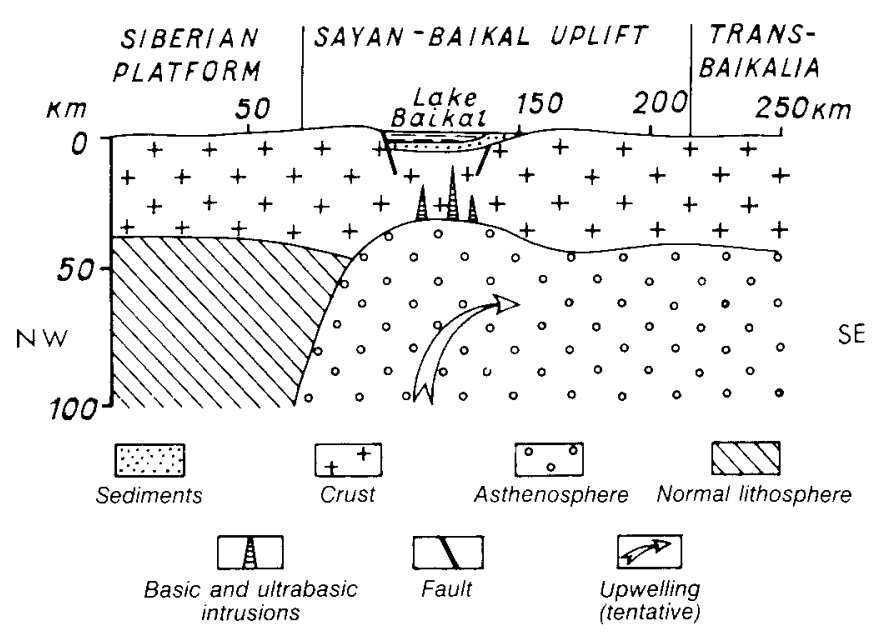

Figure 8: Deep structure of the central segment of the Baikal rift system. Arrow shows tentative direction of migration of asthenospheric material. 


\section{Conclusions}

The Baikal rift has no direct connections with the world rift system, and the daring prediction of the existence of a spreading centre there that will become an ocean in millions of years is unlikely to prove correct. The restriction of the central segment to the boundary between the craton and the mobile belt indicates favourable conditions both for lithospheric destruction, which results from its earlier geological history, and the earliest beginning of lithospheric extension in the South Baikal depression. Drilling to $3000 \mathrm{~m}$ has reached Early Oligocene or Late Eocene deposits, and beneath this, a complete section of the Eocene probably extending to the Palaeocene is undoubtedly present.

The South Baikal depression is the most ancient part of the entire rift system and the historic centre of the Baikal rift (Logatchev and Florensov, in Logatchev and Mohr, 1978). Later, mainly in the Late Oligocene and Miocene, the rifting propagated in both directions from the South Baikal basin. The flank depressions in North Mongolia and in the region between the Vitim and Olekma Rivers appeared in the Pliocene-Quaternary time. The longitudinal spread of the Baikal rift could not be synchronous and uniform because of the structural anisotropy of the basement and differences in rheological properties of the lithosphere.

In view of the propagation of the Baikal rift from the South Baikal, its symmetric morphology and structure, and the maximum uprise of the asthenosphere to the base of the crust and its possible migration from the craton, a local energy source for rifting appears to exist in the upper mantle. While not ignoring the consequences of the Indo-Eurasian plate collision for the development of inner Asia in the Cenozoic (Molnar and Tapponnier, 1975; Zonenshain and Savostin, 1981), this process does not seem to have been the driving mechanism for the development of the Baikal rift, since this is separated from the Himalaya front by a distance of over $2500 \mathrm{~km}$ and by a system of large stable and mobile tectonic domains.

The entire structural complex of the Baikal rift and the associated volcanism cannot be explained by simple mechanical spreading of the lithosphere and a constrained uprise of the asthenosphere. The main cause of the intraplate rifting in East Siberia was an upwelling and lateral migration of asthenospheric material, resulting in gravitational and heat instability of the lithosphere, the appearance of an arched uplift, rejuvenation of faults, considerable horizontal and vertical movements of crustal blocks and the formation of rift valleys. The Baikal rift is an example of the independent revival of tectonic activity in the Earth's interior, and supports the concept of asthenospheric diapirism as the initial cause of continental rifting.

\section{References (Those not in Russian are asterisked)}

*Baker, B.H., Mohr, P.A, Williams, L.A.J., 1972. Geology of the eastern rift system of Africa. Geological Society of America Special Paper no. 136, 67p.

Krylov, S.V., Mandelbaum, M.M., Mishenkin, P.P. et al., 1981. The Baikal Lake interior from seismic data. Nauka, Novosibirsk, 105p.

*Logatchev, N.A. and Mohr, P.A. (eds.), 1978. Geodynamics of the Baikal rift zone. Tectonophysics, v.45, p. 1-105.

*Logatchev, N.A., Zorin, Yu.A. and Rogozhina, V.A., 1983a. Cenozoic continental rifting and geologic formations (as illustrated by the Kenya and Baikal Rift zones). Geotectonics, v. 17, p. 83-92.

*Logatchev, N.A., Zorin, Yu.A., and Rogozhina, V.A., 1983b. Baikal Rift: active or passive? - comparison of the Baikal and Kenya Rift Zones. Tectonophysics, v. 94, p. 223-240.

Misharina, L.A., 1967. Stresses in the crust of rift zones. Nauka, Moscow, 135p.
Misharina, L.A., Melnikova, V.I., Balzhinnyam, I., 1983. Southwestern boundary of the Baikal rift zone from the data on focal mechanisms of earthquakes. Vulkanologia i seismologiya, no. 2, p. 74-83.

* Molnar, P. and Tapponnier, P., 1975. Cenozoic tectonics of Asia: Effects of a continental collision. Science, v. 189, no. 4201, p. 419-426.

*Neugebauer, H.J. and Temme, P., 1981. Crustal uplift and the propagation of failure zones. Mechanism of graben formation. Tectonophysics, v. 73, no. 1-3, p. 33-51.

* Ramberg, I.B. and Neumann, E.R., 1978. Tectonics and geophysics of continental rifts. D. Reidel, Dordrecht. 444p.

Rogozhina, V.A. and Kozhevnikov, V.M., 1979. Anomalous mantle area below the Baikal rift. Nauka, Novosibirsk, $104 \mathrm{p}$.

Yeskin, A.S., Bukharov, A.A., Zorin, Yu.A., 1978. Cenozoic magmatism at Lake Baikal. Doklady Akademiya nauk SSSR, v. 239, no. 4, p. 926-929.

*Zonenshain, L.P. and Savostin, L.A., 1981. Geodynamics of the Baikal rift zone and plate tectonics of Asia. Tectonophysics, v. 76, no. 1-2, p. 1-45.

*Zorin, Yu.A., 1981. The Baikal rift: an example of the intrusion of asthenospheric material into the lithosphere as the cause of disruption of lithospheric plates: Mechanism of graben formation. Tectonophysics, v. 73, no. 1-3, p. 91-104.

Prof. N. A. Logatchev is Director of the Institute of the Earth's Crust of the Siberian Branch of the U.S.S.R. Academy of Sciences (Lermontov St., 128, Irkutsk, 664033, U.S.S.R.), where he directs geological and geophysical investigations of the Baikal rift. He was a member of Soviet expeditions to East Africa and Iceland. He has published widely on sedimentary formations, tectonics, magmatism and continental rifting, and is a Corresponding Member of the U.S.S.R. Academy of Sciences.
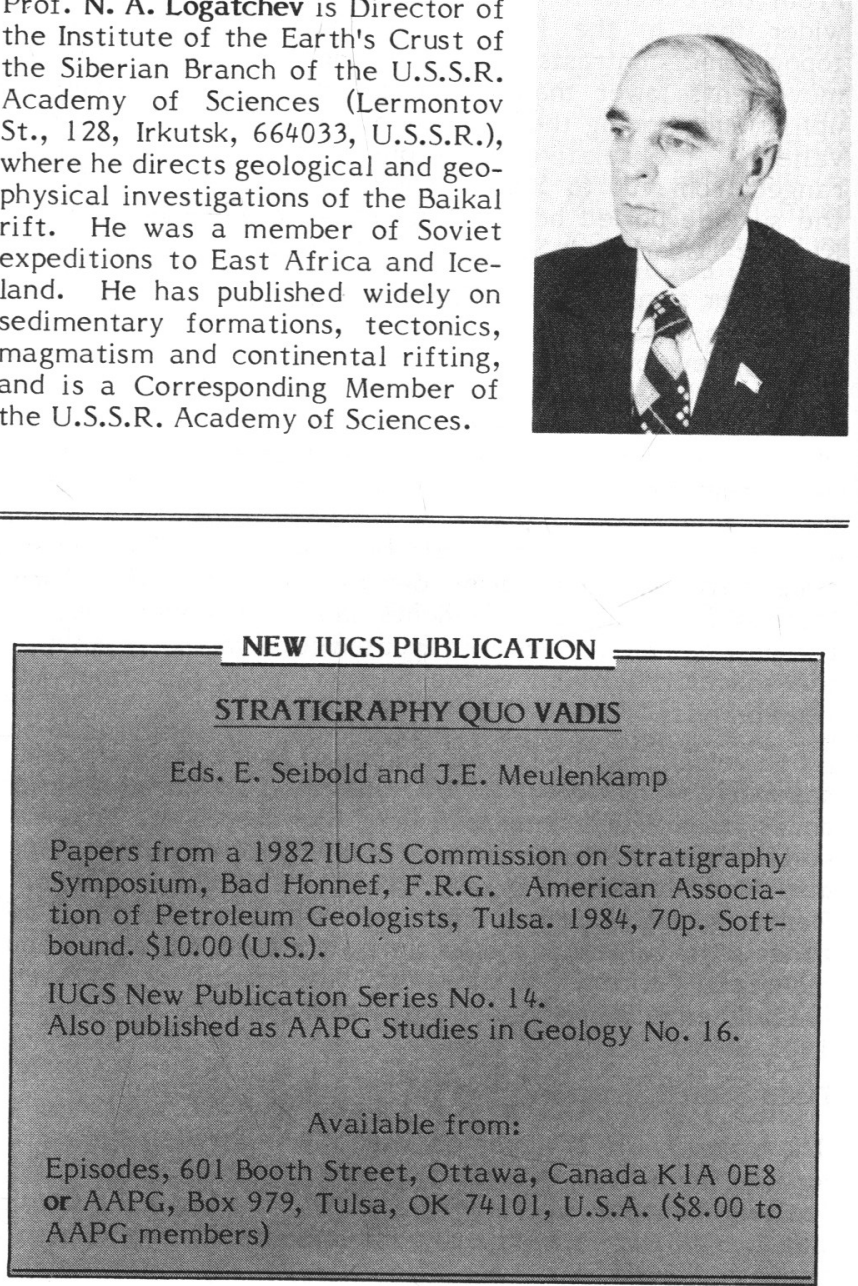